\title{
Concentration of Heavy Metals in Borehole Water from Ikono Urban, Ikono Local Government Area, Akwa Ibom State, Nigeria
}

\author{
Nwoke.I.B, Edori. E.S* \\ Department of Chemistry, Ignatius Ajuru University of Education, Rumuolumeni, P.M.B. 5047 Port Harcourt, \\ Rivers State, Nigeria
}

*Corresponding Author: Edori, Enize S, Department of Chemistry, Ignatius Ajuru University of Education, Rumuolumeni, P.M.B. 5047, Port Harcourt Rivers State, Nigeria.

\begin{abstract}
The concentration level of heavy metals ( $\mathrm{Pb}, \mathrm{As}, \mathrm{Cu}$ and $\mathrm{Fe}$ ) were assessed in five boreholes waters fromIkono Urban. Atomic Absorption Spectrometer was used to analyze the water samples. The results showed that $\mathrm{Pb}$ ranged from $0.15 \pm 0.040$ - $0.40 \pm 0.094 \mathrm{mg} / \mathrm{L} ; A s, \quad 0.05 \pm 0.008-0.10 \pm 0.041 \mathrm{mg} / \mathrm{L} ; \quad \mathrm{Cu}$, $0.02 \pm 0.008-0.06 \pm 0.016 \mathrm{mg} / \mathrm{L}$ and $\mathrm{Fe}, 0.20 \pm 0.016-0.37 \pm 0.025 \mathrm{mg} / \mathrm{L}$. The concentration levels of $\mathrm{Pb}$ and $\mathrm{As}$ in the borehole samples were above WHO, NAFDAC and SON permissible/allowable limit, Cu is lower than the allowable limit while $\mathrm{Fe}$ is within the permissible limit for drinking water. The contamination factor calculated ranged from excessively polluted for $\mathrm{Pb}$ and As, very severely contaminated for Fe and very slightly contaminated for $\mathrm{Cu}$. The pollution index revealed that the five boreholes waters were slightly polluted. The study showed that the water from the boreholes in Ikono Urbanwere contaminated with heavy metals and it has a far reaching effect on human health and therefore should be treated before being used for drinking purposes.
\end{abstract}

Keywords: Borehole, heavy metals, pollution, contamination, groundwater, water samples

\section{INTRODUCTION}

The activities of man have resulted in the contamination and pollution of nature. As a result of these continuous activities man's natural environment such as soil (land), water and air have been greatly degraded. The continuous neglect and improper implementation of programmes to mitigate these activities may have resultant effect on the life of man and other organisms that occupy the face of the earth (Adesomoye et al., 2006; Edori and Kpee, 2016). For life to effectively function, water plays an important role. The ability of man to access portable water for drinking is purely based on its availability. The wellness of life, be it man or other living creatures, depends on the availability of water for drinking and other purposes (Halilu etal, 2011). The proper use of water resources and its reach to man is a worldwide challenge, most especially in the continents of Africa and Asia (WHO, 2004).

Water as an essential tool for life on the surface of the earth is used in domestic, industrial and agricultural purposes. As the population of the world increases, there is the need for the supply of safe water for drinking, domestic, industrial and agricultural uses, so that healthy life can be achieved (Elingeet al., 2012). Water plays significant roles in the growing, development and establishment of cities and communities (Waziri etal, 2009), hence man rely on water for proper existence.

In Nigeria, due to the inability of the various levels of government to provide water for its citizens, there has arisen private boreholes indiscriminately drilled by individuals, corporate organizations and even government agencies in their different homes, and office environments (LAWMA, 2000; Edori and Kpee, 2016) to curb the menace of inadequate water supply. The alternative sources of water supply provided is uncontrolled and therefore produces negative implications on the groundwater and surface water which negates the principle of sustainable development and its goals (Abii and Nwabienvanne, 2013).

Water being a universal solvent makes it vulnerable to be easily contaminated. Polluted water is not suitable for use in all ramifications. Human influence and activities such as metal processing, oil exploration and exploitation mining and agriculture have contributed to water pollution (Kolo and 
Baba, 2004; Adeyemi and Awokunmi, 2010; Edorietal, 2016). In general, water can be primarily obtained from surface water and underground water. Underground water includes well water, borehole water while surface water sources are rivers, lakes, oceans, estuaries, creeks, streams, etc. (McMurry and Fay, 2004).

Principally, most natural water sources for agriculture and domestic uses are got underground (boreholes) (Belkhiri etal, 2018). Presently the activities of man due to advancement and urbanization has resulted in contaminating groundwater (Ozturk, etal. 2009; Momodu and Anyakora, 2010). As population increases, the desire to use land also increases and this has resulted in the pollution and contamination of the groundwater due to its vulnerability. Anthropogenic behaviours can discharge wastes and chemicals into the environment either accidentally or intentionally, which has brought about the pollution and contamination of groundwater. The remediation of contaminated groundwater is difficult and of great financial implications to restore to its normal state (Belkhiri etal, 2018).

The contamination of groundwater (boreholes) introduces heavy metals into it, although heavy metals also exist naturally underground. Heavy metals are well known contaminants of underground water, and they constitute one of the major pollutants affecting the underground water (boreholes) system (Marcovechioetal. 2007). Heavy metals are sometimes referred to as trace metals and have high density and tends to accumulate in any system not properly checked (Elingeetal. 2011). Heavy metals may be toxic and their toxicity depends on the amount available in the environment. Heavy metals leach to the groundwater when the capacity of the surface soil fails to retain them and through consumption may pass to man and other living organisms. Heavy metals are indestructible (Underwood, 1956, Edorietal., 2016). Heavy metals have the ability to exist in particulate, dissolved and colloidal phases when found in water (Adepoju-Bello et al, 2009).

The aim of this work is to determine the level of contamination of borehole waters in Ikono Urban, Ikono Local Government Area of AkwaIbom State, Nigeria.

\section{Materials AND Methods}

Water samples were collected from five locations within the Ikono Urban in the Ikono Local Government Area of Akwalbom State in a one litrejerrycan. The jerrycans were first rinsed with distilled water and then with the borehole water before filling it with the water for analysis. A representative sample was formed after three water samples were collected from each borehole at intervals of four hours, between the hours of $7.00 \mathrm{am}$ to $3.00 \mathrm{pm}$. The samples were collected in the months of December, February and April. Samples from the different stations were labelled L1, L2, L3, L4 and L5 respectively. On the same day of sampling, the samples were transported to the Jaros Base Laboratory, Port Harcourt, and Rivers State for heavy metal analysis.

Atomic absorption Spectrophotometer (AAS) was used for the determination of the concentration of heavy metals in the borehole water samples. The results of the concentration of the heavy metals obtained were presented in mg/L.factor (CF) and pollution index (PI) values from Lacatusu (2000). The contamination factor $(\mathrm{CF})$ is mathematically stated as,

$\mathrm{Cm} / \mathrm{Cb}$. Where,

$\mathrm{Cm}=$ metal concentration

$\mathrm{Cb}=$ base/background value

The background value for this work was taken from WHO (2004) limit for drinking water.

The pollution index (PI) is mathematically stated as,

$\mathrm{PI}=(\mathrm{CF} 1 \times \mathrm{CF} 2 \times \mathrm{CF} 3 \times \mathrm{CF} 4 \ldots \ldots \ldots \times \mathrm{CFn})^{1 / 4}$.

This index is used in assessing the level of pollution of heavy metals in the environment (Usero etal., 2000). Where;

$\mathrm{CF}=$ contamination factor of the individual metals and $\mathrm{n}=$ number of metals involved.

The purpose of the contamination factor and the pollution index was to measure the degree of pollution/contamination of the boreholes by heavy metals. When the contamination /pollution index value is less than one it shows contamination range while when it is greater than one it shows 
pollution range. The classification of the contamination/pollution index by Lacatusu (2000) was used to ascertain the degree of contamination/pollution of the selected heavy metals on the different boreholes.

\section{RESUlTS AND DisCUSION}

Water sample analysis results for the different heavy metals concentrations from the different boreholes are shown in Tables 1-3 and their mean concentration levels for the period under investigation is shown in Table 4. Water samples from the different boreholes in the Ikono Urban of Ikono Local Government Area of Akwalbom State revealed that Lead $(\mathrm{Pb})$ ranged between $0.15 \pm 0.040-0.40 \pm 0.094 \mathrm{mg} / \mathrm{L}$; Arsenic (As) ranged between $0.05 \pm 0.008-0.10 \pm 0.041 \mathrm{mg} / \mathrm{L}$; Copper $(\mathrm{Cu})$ ranged between $0.02 \pm 0.008-0.06 \pm 0.016 \mathrm{mg} / \mathrm{L}$ and Iron $(\mathrm{Fe})$ ranged between $0.20 \pm 0.016-$ $0.37 \pm 0.025 \mathrm{mg} / \mathrm{L}$. The contamination factor $(\mathrm{CF})$ and pollution index $(\mathrm{PI})$ of the metals in the water samples are shown in Table 6. The contamination factor recorded revealed that Lead $(\mathrm{Pb})$ ranged between 15 - 40, Arsenic (As) ranged between 5.0 - 10. Copper $(\mathrm{Cu})$ ranged between $0.01-0.03$ and Iron $(\mathrm{Fe})$ ranged between $0.67-1.23$. The pollution index for the different boreholes ranged between $1.28-1.52$.

One of the most essential and invaluable natural resources known to man is water. Water is very essential in the support for life of man on the earth, and its availability to man is a necessity for human welfare (Kumar, 2004; Ademanya, et al., 2013; Edorietal, 2016). Water of good quality is indispensable and its availability to man helps in preventing water borne diseases and helps in improving man's quality of life (Oluduro and Anyakora, 2007). As a result of man's activities or other natural factors, water comes into contact with heavy metals which are also naturally occurring. These heavy metals dissolve in the water and contaminate it. These heavy metals at a certain level of concentration in the water becomes toxic and harmful to man and other creatures that consume it (Haliluetal, 2011). The contamination of groundwater by heavy metals are of interest today because, some even at low concentrations may be toxic to humans and animals (Marcovecchioetal, 2007). However, some heavy metals when in trace quantity have significant roles in man's biochemistry, physiology and metabolism (Vinodhini and Narayanan, 2009).

Lead $(\mathrm{Pb})$ is among the non-essential heavy metals. The mean quantity of lead recorded in the various borehole samples of Ikono Urban were above the required limit for drinking water by WHO (2004), SON (2007) and NAFDAC (2011). The presence of lead in underground water (borehole) may be as a result of corrosion of plumbing works in households, industrial and mining activities and erosion (EPA, 2005), and can also be due to exploitation and exploration of crude oil and in the use of fuel laded with lead (Kpee and Edori, 2014). Lead $(\mathrm{Pb})$ when present at a high concentration resul6s in health problems to man. Heamoglobin synthesis is inhibited by lead, and due to its carcinogenic properties can cause damage to the liver and bring about hair loss in man. When man is constantly exposed to lead $(\mathrm{Pb})$, there is the possibility of delay in mental and physical development in infants and children, while in adults can cause kidney problems and high blood pressure (Imam etal, 2018). During the developmental stages of the foetus in pregnant women, the presence of lead at certain concentration can affect it and bring about disorder, even infants are vulnerable to disorder as a result of lead presence at high concentrations (Ubong and Gobo, 2001; Iyamaetal., 2014). High concentration of lead in the blood causes brain damage, irritation and also a disease known as plumbism (Edori and Edori, 2012).

Arsenic as a heavy metal prefers to exist in water at the oxidation state of +5 and at the oxidation state of +3 becomes more stable because of the absence of oxygen (WHO, 2010). The presence of arsenic in the waters of the five boreholes of Ikono Urban were all above the WHO, and other standard organizations acceptable limits for drinking water. Aarsenic when present in drinking water constitute health challenges to man and animals, and even at very low concentrations exposure to it may prove poisonous (UNICEF, 2008). One of the most environmental poisonous contaminants known is arsenic. In both oxidation states $(+5$ and +3$)$ it can be easily absorbed by the gastrointestinal tract (Smith and Steinmaus, 2007). The toxicity of arsenic is manifested in a disease known as arsenicosis, which can take about 2-20 years to appear because of its slow nature of occurrence. Toxicity due to arsenic will bring about numerous signs such as; hypo and hyper pigmentation, peripheral vascular disease, peripheral neuropathy etc. children are more vulnerable to arsenic than adults, it inhibits 
Concentration of Heavy Metals in Borehole Water from Ikono Urban, Ikono Local Government Area, Akwa Ibom State, Nigeria

intellectual development in children, stigmatization due to skin lesion that resulted from arsenicosis. This may eventually ruin the lives of growing individuals and even their families at large (UNICEF, 2013).

The mean value of copper observed from the different borehole water samples in Ikono Urban were all below the WHO, SON and NAFDAC acceptable limits allowed for drinking water. Copper is one of the essential metals needed by man for life sustenance. Copper is important in the formation of foetus, building man's immune system, development of the brain, the transmission of message by the neurons and anti-oxidative properties (Edori and Kpee, 2016). However, at high concentrations in the human body can lead to kidney and liver problems and eventual damage (EPA, 2005), irritation of the intestine and stomach, and over exposure to copper can lead to greater health hazard and risk especially for people with Wilson disease (Spinazzietal., 2007; Edorietal., 2016).

The concentration of the samples of the borehole waters from the five locations fall within the acceptable limit allowable for drinking water by the different standard organizations referenced in this work. The presence of iron in underground water at high concentrations may be due to anthropogenic activities such as welding and waste generated by man. Iron being one of the essential metals helps in the synthesis of heam proteins and the red colouration in blood. The human system also need iron to fight disease causing bacteria (Adriano, 2001). The concentration of iron above allowable level can result in cell damage of the gastrointestinal tract, heart and liver. Iron in excess may result in metabolic and genetic diseases which bring about blood transfusion repeatedly in patients (Anakeetal., 2014; Iyamaetal; 2014). The brown colouration in water comes about when iron is in excess and then exposed to the air, which then converts the iron from its oxidation state of +2 to +3 .

Table1. Concentrations of Heavy Metals in Borehole Samples from Ikono Urban in Akwalbom State in December

\begin{tabular}{|c|c|c|c|c|c|}
\hline \multirow{2}{*}{$\begin{array}{c}\text { Heavy Metals } \\
(\mathrm{mg} / \mathrm{L})\end{array}$} & \multicolumn{5}{|c|}{ Stations } \\
\cline { 2 - 6 } & $\begin{array}{c}\text { NdinyaMfia } \\
\text { (L1) }\end{array}$ & $\begin{array}{c}\text { NungUkim } \\
\text { (L2) }\end{array}$ & $\begin{array}{c}\text { ItonOdoro } \\
\text { (L3) }\end{array}$ & IbiakuNtokOkpo (L4) & $\begin{array}{c}\text { NdiyaEtok } \\
\text { (L5) }\end{array}$ \\
\hline $\mathrm{Pb}$ & 0.2 & 0.5 & 0.3 & 0.5 & 0.3 \\
\hline $\mathrm{As}$ & 0.12 & 0.08 & 0.10 & 0.14 & 0.06 \\
\hline $\mathrm{Cu}$ & 0.05 & 0.03 & 0.06 & 0.02 & 0.04 \\
\hline $\mathrm{Fe}$ & 0.26 & 0.31 & 0.29 & 0.18 & 0.40 \\
\hline
\end{tabular}

Table2. Concentrations of Heavy Metals in Borehole Samples from Ikono Urban in Akwalbom State in February

\begin{tabular}{|c|c|c|c|c|c|}
\hline \multirow{2}{*}{$\begin{array}{c}\text { Heavy } \\
\text { Metals } \\
(\mathrm{mg} / \mathrm{L})\end{array}$} & $\begin{array}{c}\text { NdinyaMfia } \\
(\mathrm{L} 1)\end{array}$ & $\begin{array}{c}\text { NungUkim } \\
(\mathrm{L} 2)\end{array}$ & $\begin{array}{c}\text { ItonOdoro } \\
(\mathrm{L} 3)\end{array}$ & IbiakuNtokOkpo (L4) & $\begin{array}{c}\text { NdiyaEtok } \\
(\text { L5) }\end{array}$ \\
\hline & 0.1 & 0.2 & 0.1 & 0.3 & 0.24 \\
\hline $\mathrm{Pb}$ & 0.08 & 0.08 & 0.06 & 0.06 & 0.04 \\
\hline $\mathrm{As}$ & 0.04 & 0.02 & 0.04 & 0.01 & 0.03 \\
\hline $\mathrm{Cu}$ & 0.29 & 0.32 & 0.36 & 0.20 & 0.34 \\
\hline $\mathrm{Fe}$ & & &
\end{tabular}

Table3. Concentrations of Heavy Metals in Borehole Samples from Ikono Urban in Akwalbom State in April

\begin{tabular}{|c|c|c|c|c|c|}
\hline \multirow{2}{*}{$\begin{array}{c}\text { Heavy } \\
\text { Metals } \\
(\mathrm{mg} / \mathrm{L})\end{array}$} & $\begin{array}{c}\text { NdinyaMfia } \\
(\mathrm{L} 1)\end{array}$ & $\begin{array}{c}\text { NungUkim } \\
\text { (L2) }\end{array}$ & $\begin{array}{c}\text { ItonOdoro } \\
\text { (L3) }\end{array}$ & $\begin{array}{c}\text { IbiakuNtokOkpo } \\
\text { (L4) }\end{array}$ & NdiyaEtok (L5) \\
\hline $\mathrm{Pb}$ & 0.15 & 0.20 & 0.20 & 0.50 & 0.27 \\
\hline $\mathrm{As}$ & 0.18 & 0.08 & 0.08 & 0.10 & 0.05 \\
\hline $\mathrm{Cu}$ & 0.06 & 0.04 & 0.08 & 0.03 & 0.05 \\
\hline $\mathrm{Fe}$ & 0.27 & 0.33 & 0.33 & 0.22 & 0.38 \\
\hline
\end{tabular}

Table4. Mean Concentrations of Heavy Metals in Borehole Samples from Ikono Urban in Akwalbom State in the Sampled Months

\begin{tabular}{|c|c|c|c|c|c|}
\hline \multirow{2}{*}{$\begin{array}{c}\text { Heavy } \\
\text { Metals } \\
(\mathrm{mg} / \mathrm{L})\end{array}$} & $\begin{array}{c}\text { NdinyaMfia } \\
(\mathrm{L} 1)\end{array}$ & $\begin{array}{c}\text { NungUkim } \\
(\mathrm{L} 2)\end{array}$ & $\begin{array}{c}\text { ItonOdoro } \\
(\mathrm{L} 3)\end{array}$ & IbiakuNtokOkpo (L4) & $\begin{array}{c}\text { NdiyaEtok } \\
(\text { L5) }\end{array}$ \\
\hline $\mathrm{Pb}$ & $0.15 \pm 0.040$ & $0.30 \pm 0.141$ & $0.20 \pm 0.082$ & $0.40 \pm 0.094$ & $0.27 \pm 0.025$ \\
\hline $\mathrm{As}$ & $0.10 \pm 0.041$ & $0.08 \pm 0.00$ & $0.08 \pm 0.016$ & $0.10 \pm 0.033$ & $0.05 \pm 0.008$ \\
\hline $\mathrm{Cu}$ & $0.05 \pm 0.008$ & $0.03 \pm 0.008$ & $0.06 \pm 0.016$ & $0.02 \pm 0.008$ & $0.04 \pm 0.008$ \\
\hline $\mathrm{Fe}$ & $0.27 \pm 0.012$ & $0.032 \pm 0.008$ & $0.33 \pm 0.029$ & $0.20 \pm 0.016$ & $0.37 \pm 0.025$ \\
\hline
\end{tabular}


Concentration of Heavy Metals in Borehole Water from Ikono Urban, Ikono Local Government Area, Akwa Ibom State, Nigeria

Table5. Approved Standards for the Selected Metals in Drinking Water

\begin{tabular}{|l|l|l|l|}
\hline Heavy Metals & NAFDAC & SON & WHO \\
\hline $\mathrm{Pb}$ & 0.01 & 0.01 & 0.01 \\
\hline $\mathrm{As}$ & 0.01 & 0.01 & 0.01 \\
\hline $\mathrm{Cu}$ & 1.00 & 1.00 & $0.5-2.0$ \\
\hline $\mathrm{Fe}$ & 0.30 & 0.30 & 0.30 \\
\hline
\end{tabular}

The level of contamination and pollution of the boreholes when observed from the contamination factor and pollution index significant intervals (Lacatusu, 2000), a standard normally used to verify the level of contamination/pollution due to contamination effect from heavy metals revealed that the borehole waters are excessively polluted with $\mathrm{Pb}$ and $\mathrm{As}, \mathrm{Cu}$ is very slightly contaminated and $\mathrm{Fe}$ is very severely contaminated. Considering the heavy metals used $(\mathrm{Pb}, \mathrm{As}, \mathrm{Cu}$ and $\mathrm{Fe})$, the pollution index from the results showed that water from the different boreholes were slightly polluted.

The contamination/pollution index values according to Lacatusu (2000) are; < 0.1 is very slightly contaminated, $0.10-0.25$ is slightly contaminated, $0.26-0.5$ is moderately contaminated, $0.51-0.75$ is severely contaminated, $0.76-1.00$ is very severely contaminated, $1.1-2.0$ is slightly polluted, 2.1 -4.0 is moderately polluted, $4.1-8.0$ is severely polluted, $8.1-16.0$ is very severely polluted and > 16 is excessively polluted.

Table6. Contamination Factor and Pollution Index of Borehole Water from Ikono Urban in AkwaIbom State

\begin{tabular}{|c|c|c|c|c|c|}
\hline Heavy Metals & \multicolumn{5}{|c|}{ Stations } \\
\cline { 2 - 6 } & $\begin{array}{c}\text { NdinyaMfia } \\
\text { (L1) }\end{array}$ & $\begin{array}{c}\text { NungUkim } \\
\text { (L2) }\end{array}$ & $\begin{array}{c}\text { ItonOdoro } \\
\text { (L3) }\end{array}$ & IbiakuNtokOkpo (L4) & $\begin{array}{c}\text { NdiyaEtok } \\
\text { (L5) }\end{array}$ \\
\hline $\mathrm{Pb}$ & 15 & 30 & 20 & 40 & 27 \\
\hline $\mathrm{As}$ & 10 & 8 & 8 & 10 & 5 \\
\hline $\mathrm{Cu}$ & 0.025 & 0.015 & 0.03 & 0.01 & 0.02 \\
\hline $\mathrm{Fe}$ & 0.9 & 1.07 & 1.10 & 0.67 & 1.23 \\
\hline Pollution Index & 1.36 & 1.40 & 1.52 & 1.28 & 1.35 \\
\hline
\end{tabular}

\section{CONClusion}

The study revealed that the concentration level of heavy metals in the different boreholes within the Ikono Urban is at a level that needed to be controlled, especially $\mathrm{Pb}$ and as which were above the WHO allowable limit for drinking water. The poor quality of drinking water within the locality is typical of a third world country like Nigeria. Urgent steps should be taken to forestall accumulation in order to overcome any water borne disease and other related health hazard due to heavy metals accumulation.

\section{REFERENCES}

[1] Abii, T. A. and Nwabievanne, E. U. (2013). Investigation of trace metal content on some selected borehole waters around Umuahia metropolis. Research Journal of Applied Science, 2(4): 494-496.

[2] Adepoju-Bello, A. A., Ojomolade, O. O. Ayoola, G. A. and Coker, H. A. B. (2009). Quantitative analysis of some toxic metals in domestic water obtained from Lagos metropolis. The Nig. J. Pharm., 42(1): 57-60.

[3] Adesemoye, O. A. Opere, B. O. and Makinde, S. C. O. (2006). Microbial content of abattoir waste and its contaminated soil in Lagos, Nigeria. African Journal of Biotechnology, 5(20): 1963-1968.

[4] Adeyemi, S. O. and Awokunmi, E. E. (2010). Heavy metals in water samples from Itaogbolu area of Ondo State, Nigeria. African Journal of Environmental Science and Technology, 4(3): 145-148.

[5] Adriano, D. C. (2001). Trace metals in terrestrial environment. Bioavalability and Risk of Metalsm, 3 : 133.

[6] Adumanya, O. C. U., Akunna, T. O., Lele, K. C. and Ogu, U. J. F. (2013). Assessment of heavy metals in borehole water in Umuagwo-Ohaji L. G. A., Imo State. International Journal of Research and Reviews in Pharmacy and Applied Science, 3(3): 315-320.

[7] Anake, W. U., Benson, N. U., Akinsiku, A. A., Ehi-Eromosele, C. O. and Adeniyi, O. I. (2014). Assessment of trace metals in drinking water and groundwater sources in Ota, Nigeria. International Journal of Scientific and Research Publications, 4:5.

[8] Belkhiri, L., Tiri, A. and Mouni, L. (2018). Assessment of heavy metals contamination in groundwater. A case study of the South of setif Area, East Algeria. Achievement and Challenges of Integrated River Basin Management: 17-31. 
[9] Edori, O. S. and Kpee, F. (2016). Physicochemical and heavy metal assessment of water samples from boreholes near some abattoirs in Port Harcourt, Rivers State, Nigeria. American Chemical Science Journal, 14(3): 1-8.

[10] Edori, O. S. and Edori, E. S. (2012). Effect of automechanic works on lead and iron in two Mechanic Villages in Port Harcourt, Rivers State, Nigeria. Journal of Applied Science and Environmental Management, 16(4): 317-321.

[11] Edori, O. S., Nwoke, I. B. and Iyama, W. A. (2016). Heavy metas and physicochemical parameters of selected borehole water from Umuechem, Etche Local Government Area, Rivers State, Nigeria. International Journal of Chemistry and Chemical Engineering, 6(1): 45-57.

[12] Elinge, C. M., Itodo, A. U. Peni, I. J., Birnin-Yauri, U. A. and Mbongo, A. N. (2011). Assessment of heavy metals concentrations in bore-hole waters in Aliero Community of Kebbi State. Advances in Applied Research, 2(4): 279-282.

[13] Halilu, M., Modibbo, U. U. and Haziel, H. (2011). Determination of heavy metal concentration in sachet water sold in Gombe metropolis. BOMJ, 8(1): 15-19.

[14] Imam, M. M., Kankara, I. L. and Abba, Y. (2018). Determination of some heavy metals in borehole and well water from selected industrial araes of Kaduna metropolis. Discovery Science, 4: 93-99.

[15] Iyama, W. A., Edori, O. S. and Ikpe, S. (2014). Study of pollution levels in Ahoada-Ihuaba axis of Sombreiro River, Ahoada, Rivers State, Nigeria. International Research Journal of Pure and Applied Chemistry, 4(4): 378-387.

[16] Kpee, F. and Edori, O. S. (2014). Trace metals content in shore crabs (Cardisomaguanhumi) from coastal area of Port Harcourt City, Rivers State, Nigeria. Archives of Applied Science Research, 6(6): 16-21.

[17] Kolo, B. G. and Baba, S. (2004). Analysis of some water samples from Hong Local Government Area of Adamawa State, Nigeria. Bornu Journal of Geology, 3(4-5): 54-59.

[18] Kumar, A. (2004). Water pollution: A. P. H. Publishing Corporation, New Delhi, India, 199.

[19] Lacatusu, R. (2000). Appraising levels of soil contamination and pollution with heavy metals. European Soil Bureau Research Report, 4: 393-402.

[20] Lagos State Waste Management Authority (LAWMA) (2000). Management of landfill waste; The journey so far.

[21] Marcovecchio, J. E., Botte, S. E. and Freije, R. H. (2007). Heavy metals, major metals, trace metals. In: Nollet, L. M. editor. Handbook of Water Analysis. 2nd ed. London: CRC Press, 273-311.

[22] McMurry, J. and Fay, R. C. (2004). Hydrogen, oxygen and water. In: McMurry fay Chemistry. K. P. Hamann, (Ed.) $4^{\text {th }}$ Edn. New Jersey: Pearson Education, 575-599.

[23] Momodu, M. A. and Anyakora, C. A. (2010). Heavy metal contamination of groundwater. The Surulere case study. Research Journal of Environmental and Earth Sciences, 2: 39-43.

[24] NAFDAC (national Agency for Food, Drug Administration and Control) (2001). Guidelines on Drinking water quality. NAFDAC consumer bulletin, October - December, 1: 9

[25] Nigerian Industrial Standard (NIS) (2007). Nigerian Standard for Drinking water quality. Standard Organization of Nigeria (SON), Lagos, Nigeria.

[26] Oluduro, M. A. and Anyakora, C. A. (2007). Heavy metals contamination of groundwater. The Surulere case study. Research Journal of Environmental and Earth Sciences, 2(1): 39-43.

[27] Ozturk, M., Ozozen, G., Minareci, O. and Minareci, E. (2009). Determination of heavy metals in fish, water and sediments of Avsar Dam Lake in Turkey. Iranian Journal of environmental Health Science and Engineering, 6: 73-80.

[28] Smith, A. and Steinmaus, C. (2007). High concentrations of arsenic in drinking water results in the highest known increases in mortality attributable to any environmental exposure. In: Paper presented at the "Arsenic in drinking water a global threat to health" Sessions of the Royal Geographic Society Annual Conference. Available: http//www.rgs.org.

[29] Spinazzi, M., De Lazzari, F., Tavolato, B., Angelina, C., Manara, R. and Armani, M. (2007). Myelooptico-neuropathy in copper deficiency occurring after partial

[30] gastrectomy. Do small bowel bacterial overgrowth syndrome and occult zinc ingestion tip the balance. Journal of Neurology, 254: 1012-1017.

[31] Ubong, I. U. and Gobo, A. E. (2001). Fundamentals of Environmental Chemistry. $1^{\text {st }}$ Edition, Tom and Harry Publications Ltd., Port Harcourt Nigeria. 
[32] Underwood, E. J. (1956). Trace elements in humans and animals' nutrition. $3^{\text {rd }}$ ed. New York: Academic Press.

[33] UNICEF (2008). Arsenic Mitigation in Bangladesh.

[34] UNICEF (2013). Arsenic contamination in groundwater.

[35] United States Environmental Protection Agency (EPA) (2005). Groundwater Current Standards. National Primary Drinking Water Standards, 1-12.

[36] Usero, J. A., Garcia, J., Fraidiascalidad de las agues y Sedimentos del LitoralAndeluz, In: Junta de Andelicia, Consejeria del Medio ambiente, Sevilla, (Editorial); 164.

[37] Vinodhini, R. and Narayanan, M. (2009). The impact of heavy metals on the hematological parameters in common carp (Cyprinuscarpio). Iranian Journal of Environmental Health Science and Engineering, 6(1): 23-28.

[38] Waziri, M., Ogugbuaja, V. O. and Dimari, G. A. (2009). Heavy metals concentrations in surface and groundwater samples from Gashua and Nguru Areas of Yobe State, Nigeria. Integrated Journal of Science and Engineering, 8(1): 58-63.

[39] WHO (2004). World health Organization Guidelines for drinking-water quality, $3^{\text {rd }}$ edn, World Health Organization, Geneva. Quality. 3 vol. 1.

[40] World Health Organization (Who) (2010). Guidelines for Drinking-Water Quality, Water for Health, Geneva.

Citation: Edori Enize S and Nwoke.I.B., " Concentration of Heavy Metals in Borehole Water from Ikono Urban, Ikono Local Government Area, Akwa Ibom State, Nigeria”, International Journal of Advanced Research in Chemical Science, vol. 7, no. 1, p. 27-33, 2020. DOI: http://dx.doi.org/10.20431/23490403.0701005

Copyright: () 2020 Authors. This is an open-access article distributed under the terms of the Creative Commons Attribution License, which permits unrestricted use, distribution, and reproduction in any medium, provided the original author and source are credited. 